\title{
EVALUATION OF HAEMOSTATIC EFFECT OF CYNODON DACTYLON PERS IN ALBINO RATS
}

Leela Hugar ${ }^{1}$, Ramesh $\mathrm{H}^{2}$

\section{HOW TO CITE THIS ARTICLE:}

Leela Hugar, Ramesh H. "Evaluation of Hemostatic Effect of Cynodon Dactylon Pers in Albino Rats". Journal of Evolution of Medical and Dental Sciences 2014; Vol. 3, Issue 11, March 17; Page: 2711-2713,

DOI: $10.14260 /$ jemds/2014/2197

\begin{abstract}
OBJECTIVES: To evaluate the haemostatic activity of Cynodon dactylon pers (CD) in albino rats. METHODS: 12 rats were divided into two groups (control and test) with 6 rats in each group. Determination of Bleeding Time (BT): The rat tail was warmed for one minute in water at $40^{\circ} \mathrm{C}$ and then dried. A small cut was made in the middle of the tail with a scalpel. In test group, a drop of fresh juice of CD was applied on the injured area immediately after making the cut in the middle of the tail, where as in the control group nothing was applied and BT estimated. Determination of Clotting Time (CT): 12 test tubes were arranged in water bath at $37^{\circ} \mathrm{C}$. Control Group: $0.4 \mathrm{ml}$ of blood was collected from each rat in the control group and added to 6 test tubes kept in the water bath. Test group: For the remaining 6 test tubes $0.1 \mathrm{ml}$ of freshly prepared juice of CD was added. $0.4 \mathrm{ml}$ of blood collected from the test group was added to these test tubes. The CT was estimated for both control group and test group. RESULTS: The BT in control group was $160.5 \pm 8.3$ sec and in test group $96.8 \pm 10.3 \mathrm{sec}$. The CT in control group was 507.6 $\pm 18.2 \mathrm{sec}$ and in test group $319.3 \pm 27.1 \mathrm{sec}$. The results were statistically analyzed by using t-test. A p value of $<0.05$ was considered for statistical significance. CONCLUSION: In this study the freshly prepared juice of Cynodon dactylon pers significantly reduced both BT and CT in the test group.
\end{abstract}

KEYWORDS: Cynodon dactylon, haemostatic effect, albino rats.

INTRODUCTION: Cynodon dactylon pers (CD) is a perennial weedy grass distributed all over the world including most parts ofIndia ${ }^{1}$. The expressed juice of the plant is traditionally applied to cuts and wounds to arrest bleeding2. It is also used in epistaxis. ${ }^{3,4}$ Oral administration of the juice of the plant is effective in treating menorrhagia.5,6 As CD grows widely as a weed, it is a natural resource which can be explored. The scientific report on its haemostatic activity in controlled experiments is relatively scanty. This study is therefore undertaken to evaluate its possible haemostatic activity in albino rats.

\section{MATERIALS AND METHODS:}

Preparation of Cynodon Dactylon Juice Extract: The leaves of Cynodon dactylon pers were collected from the outskirts of Hubli city. The leaves were crushed mechanically and the juice of about $100 \mathrm{ml}$ was extracted. The juice was immediately used.

Experimental Animals: 12 healthy albino rats of wistar strain of either sex weighing between 200$250 \mathrm{~g}$ were used for the study. The animals were housed under standard conditions and were provided food and water ad libitum. The study was approved by the institutional ethical committee, KIMS Hubli.

12 rats were divided into two groups (control and test) with 6 rats in each group. 
Determination of Bleeding Time (BT): ${ }^{7}$ In control group, the rat tail was warmed for one minute in water at $40^{\circ} \mathrm{C}$ and then dried. A small cut was made in the middle of the tail with a scalpel. Bleeding time started when the first drop touched the circular filter paper. It was checked at 30 sec intervals until the paper no longer stained with blood. The time taken for bleeding to stop was recorded for each rat and the average was taken as bleeding time. In test group, after making a small cut in the middle of the tail with scalpel and blood had started coming out, a drop of juice of CD was dropped on the injured site and bleeding time was recorded in the same way as in control group.

Determination of Clotting Time (CT): ${ }^{8} 12$ test tubes were arranged in water bath at $37^{\circ} \mathrm{C} .0 .1 \mathrm{ml}$ of freshly prepared juice of $\mathrm{CD}$ was added to six test tubes while nothing was added to the remaining 6 test tubes. Blood was collected directly from the heart of each rat after ether anesthesia. $0.4 \mathrm{ml}$ of blood collected from each rat was then delivered into each tube. The stopwatch was started immediately after the blood started flowing into the syringe and tubes were continually tilted at 40 sec intervals until blood in them stopped flowing when tilted at an angle of $90^{\circ}$. The average of the clotting time of each group was recorded.

STATISTICAL ANALYSIS: All results were expressed as mean \pm SEM and the results were compared statistically by t- test. A p value $<0.05$ was considered statistically significant.

RESULTS: The CD juice significantly $(\mathrm{p}<0.05)$ decreased bleeding time in test group as compared to control group. The mean bleeding time for control group was $160.5 \pm 8.3 \mathrm{sec}$ while that for test group was $96.8 \pm 10.3 \mathrm{sec}$. There was also significant reduction in clotting time $(\mathrm{p}<0.05)$ in test group compared to control group. The mean clotting time for control group was507.6 \pm 18.2 second that for test group was $319.3 \pm 27.1 \mathrm{sec}$.

DISCUSSION: This study was undertaken to evaluate the haemostatic activity of the juice of the leaves of CD with primary interest on how it affects bleeding and clotting time respectively. The study showed that CD juice significantly reduced bleeding time which is a measure of blood coagulation.

Bleeding time evaluates the vascular and platelet responses associated with haemostasis. The juice of CD reduced BT possibly by acting on the integrity of the blood vessel or enhancing the formation of platelet plug. CD showed the presence of flavonoids, alkaloids and tannins, many of which are biologically active phytochemicals ${ }^{9}$.Tannins have been implicated in the haemostatic activity of plants where they arrest bleeding from damaged or injured vessels by precipitating proteins to form vascular plugs ${ }^{10}$. CD juice also significantly reduced clotting time, which is another measure of blood coagulation. The juice of CD reduced CT possibly by enhancing the coagulation process by intrinsic path way which may involve the reaction of factor XII, factor XI, factor IX or factor VIII. As this study is encouraging, further studies are required to explain the mechanisms involved in the haemostatic property of CD.

\section{REFERENCES:}

1. Sudarshan SR. Encyclopaedia of Indian Medicine vol 4. Bombay: Popular Prakashan Pvt. Ltd; 2006.

2. Kumar A, Sawarkar HA, Deshmukh V S, Mishra K K, Singh M, Verma T, Kashyap P. Cynodon dactylon (L.) Pers: Pharmacological actions and medicinal applications. International Journal of Herbal Drug Research2011; I (1):1-7. 
3. Srivastava T N, Rajasekharan S, Badola D P, Shahan D C. An index of the available medicinal plants, used in Indian system of medicine from Jammu and Kashmir State. Ancient Science of Life.1986 July1; VI: $49-63$.

4. Datta K A, Mandal A, Paul R. An update overview on Cynodon dactylon (L.) pers. International Journal of Research in Ayurveda and Pharmacy. 2012Jan-Feb; 3(1):11-14.

5. Thakare V M, Chaudhari R Y, Patil V R. Potential medicinal plant cynodon dactylon (L.) pers. Asian Journal of Pharmaceutical Sciences and Research 2011 Nov; 1(6):1-9.

6. Solanki R, Nagori BP. Physicochemical and phytochemical investigation of whole plant of cynodon dactylon. International journal of comprehensive pharmacy2012; 3(10):1-4.

7. García-Manzano A, González-Llaven J, Lemini C, Rubio-Póo C. Standardization of rat blood clotting tests with reagents used for humans. Proceedings of the Western Pharmacology Society.2001; 44:153-155.

8. Weremfo A, Adinortey MB, Pappoe ANM. Hemostatic Effect of the stem juice of Musa paradisiaca L. (Musaceae) in guinea pigs. Advances in Biological Research 2011; 5 (4):190-192.

9. Kumar A, Kashyap P, Sawarkar H, Muley B, Pandey A. Evaluation of antibacterial activity of Cynodon dactylon (L.) pers. International Journal of Herbal Drug Research 2011; I(II):31-35.

10. Tanko Y, Eze ED, Jimoh A, Yusuf K, Mohammed K A, Balarabe F, Mohammed A. Haemostatic effect of aqueous extract of mushroom (Ganoderma lucidum). European Journal of Experimental Biology 2011; 2(6):2015-2018.

\begin{tabular}{|c|c|c|}
\hline Parameter & Control group & Treatment group \\
\hline Bleeding time(sec) & $160.5 \pm 8.3$ & $96.8 \pm 10.3$ \\
\hline Clotting time (sec) & $507.6 \pm 18.2$ & $319.3 \pm 27.1$ \\
\hline \multicolumn{2}{|r|}{ Haemostatic effects of Cynodon Dactylon pers juice in albino Rats }
\end{tabular}

\section{AUTHORS:}

1. Leela Hugar

2. Ramesh $\mathrm{H}$.

\section{PARTICULARS OF CONTRIBUTORS:}

1. Post Graduate, Department of Pharmacology, KIMS, Hubli.

2. Associate Professor, Department of Pharmacology, KIMS, Hubli.

\section{NAME ADDRESS EMAIL ID OF THE} CORRESPONDING AUTHOR:

Dr. Leela Hugar,

Post Graduate,

Department of Pharmacology,

Karnataka Institute of Medical Sciences,

Vidyanagar, Hubli - 580022.

E-mail: leela146@gmail.com

Date of Submission: 18/02/2014.

Date of Peer Review: 19/02/2014.

Date of Acceptance: 27/02/2014.

Date of Publishing: 11/03/2014. 